\title{
Agricultural reforms in Russia from 1856 to the present: Successes and failures in the international comparative perspective
}

\author{
S. Merl
}

Stephan Merl, DSc (History), Professor, Bielefeld University; Universitätsstr., 25, 33615, Bielefeld, Germany. E-mail: stephan.merl@uni-bielefeld.de.

Despite its initial backwardness, the agricultural sector played a decisive role in the Russian/Soviet history. Until the 1950s, it was the main sector of occupation; it had contributed greatly to the gross domestic product and gross value added until forced collectivization destroyed huge agricultural resources. The article argues that emancipation paved the way for agricultural modernization by promoting a new agricultural structure based on the market and the skills of the heads of large-scale and family farms. The author identifies three Russian/Soviet approaches to the agrarian reform (1856-1928, 1929-1987, from 1987) in terms of contribution to the modernization of agriculture and of catching up with the developed countries. The article argues that until 1928 and (after the agricultural depression of the 1990s) from 2000, Russia was successful in both modernization and catching up, while Stalin's forced collectivization at first led to stagnation. After the World War II, forced collectivization prevented any "green revolution" (i.e. application of the agricultural scientific research findings). Under the state command system in agriculture, poor mechanization did not increase the labor productivity. Although Russia was known for agricultural surpluses before collectivization, the late Soviet Union became a major grain importer. Only the reform that started in 1987 removed the state command system to make the agricultural producers masters of their fields again, which led to a considerable increase in agricultural productivity since 2005. Basing the reappraisal of the agrarian reforms on the recent successes, the article likes to encourage further discussion. It proposes to regard the use of the available rural labor force, the quality of the industrial inputs in agriculture and the extent to which the producers were allowed to be masters of their agricultural production as the most appropriate criteria for assessing the agrarian reforms' results.

Key words: agrarian reform, efficiency of agricultural production, emancipation, forced collectivization, green revolution, mechanization of agriculture, modernization, peasant farms, rural underemployment, socialist industrialized agriculture, Alexander II, Stalin, Brezhnev, Khrushchev, Gorbachev, Putin.

DOI: $10.22394 / 2500-1809-2020-5-2-56-87$

\section{Introduction}

Unlike Western Europe, the Russian emancipation focused on giving the peasants personal freedom and some land. Therefore, measures of agricultural modernization as ensuring free surplus labor and im- 
proving its use were only the tasks of the Stolypin reform in 1906 and Bolshevik's "turning to the village" (litsom k derevne) in 1924. I consider the time from 1861 to 1928 as one period of peasant farms developing to adapt to the market.

Forced collectivization abruptly ended the development of private farming and put agriculture under the state command (1929-1987), which had disastrous consequences not only for agriculture. Peasants were forced to join the so-called "collective" farms that were in every aspect under the state control. They did not pay workers and kept their members at their home places in the status similar to the forced workers. Instead of returning to private agriculture after Stalin's death, Khrushchev and Brezhnev kept agriculture under the state command. Their attempts to increase efficiency by complex mechanization failed. Thus, the basic questions are: Why the efficiency of the socialist large-scale agriculture was so extremely poor in the international comparative perspective and why did it miss the "green revolution"? How can the extreme waste of invested resources under Brezhnev be explained? Why did agrarian science, highly developed in the international perspective and affecting the development of peasant farms in the early 2oth century, have so little impact on policies and practice of agricultural production?

Under the failure of the state command system, the third reform period started in 1987 and aimed at reviving peasant consciousness to make the heads of agricultural enterprises "masters" of their fields again. Putin's food security program contributed to overcoming the agricultural depression of the 199os and stabilized agricultural production. The use of economic levers still put the production risks on producers, but the reform brought Russia back on the successful path of agricultural modernization. Today plant and animal yields significantly exceed the highest Soviet numbers. As the agricultural gross production today is not higher than at the beginning of the 199os, the enormous waste of resources before is evident.

There are many studies of separate reforms but not of the whole modernization of the Russian agriculture from 1856 to the present. In 2011, Carol Leonard published a book on the agrarian reforms in Russia The Road from Serfdom, and I will show that today's issues are the legacy of collectivization. Her book provides many references on recent studies of the agricultural reform (Leonard, 2011: 299398). This article is based on my previous research (Merl, 1981; 1985b; 1990a; 1993; 2002a; 2016; 2019) and recent work in the archives. The most important recent research of the Russian peasantry pre-collectivization was conducted by David Moon (1999; 2001) and of the Russian agriculture from 2000 to the present - by Wegren, Nikulin, and Trotsuk (2018).

The study of agrarian reforms means to consider modernization for a successful reform only partly depends on the state - actions "from above". The impulses "from below", the needs of the production 
process itself and of producers are of crucial importance. To achieve its goals, the reform needs their support, people have to understand история its tasks and accept them in their agricultural activities. Therefore, to be successful the agrarian reform has to change people's behavior, which explains why it takes so much time, about a generation, to assess the results. It is also necessary to consider the reformers' views. They were not, as Leonard argues (2011: 6, 271), "bureaucrats" in the negative meaning of the word. The 1861 emancipation act was introduced by a small group of "enlightened bureaucrats" with a clear, though "ideological", concept of the reform, who wanted to create a better world without bonded labor. The so-called "Stolypin reform" was developed by excellent specialists under the guidance of Witte already in the $18 \mathrm{gos}$. The program of collectivization within the first five-year plan was at first developed by highly qualified specialists of the State Planning Commission (Gosplan) and Commission on Agriculture. There was no organizational work on collectivization under Stalin in 1929, which neglected all recommendations and warnings of the experts.

\section{On the path from emancipation to peasant family farms (1856-1928)}

In his address to the Moscow nobles on March 30,1856 , Alexander II first announced his intention to abolish serfdom and asked the nobles to make suggestions. The period between 1856 and the emancipation act of 1861 was described in detail (Beyrau, 1981; Scheibert, 1973; Moon, 2001) - Alexander II did not know how to implement his plan. The majority of the nobles objected to it and made no suggestions hoping that nothing would happen. Only a tiny group of "enlightened bureaucrats" (Lincoln, 1972) in the state apparatus finally took necessary measures and significantly shaped the emancipation act with their ideas and views.

Alexander II mainly wanted to get rid of the morally questionable institution without social unrest. He tried not to hurt the contradictory interests of both nobles and serfs, which was a difficult task. Every peasant household got the right to get a land allotment but had to pay for it - in peasants' perception it was god's land belonging to those working on it. They never thought that after becoming free they would have to work for two more years for landowners. During this period, representatives of the peasant land communes were to settle with their nobles the local arrangement of redemption. However, peasants in general did not rebel for the tsar for the first time in history addressed them in the emancipation decree and made them equal partners of the nobles in bargaining (Merl, 2018). It was the nobles and not the peasants, as Leonard argues (2011: 42-43), who started the politically dangerous protest: many nobles felt betrayed by the 
tsar. For the first time in the Russian history they required constitutional participation in the state legislation, which was granted only 45 years later with the 1905 October decree.

To keep social peace, the state declared that to get the land property rights the peasants were to pay only 20 percent of the land price to the nobles - for 80 percent the state granted loans to the peasant communes, which were to be repaid in small rates in the next 50 years. To ensure it, peasants were made collectively responsible and bound to their land communes for this period. Peasant emancipation without land was not acceptable for land redemption was to guarantee that peasants would be able to pay taxes and fees to the state (Beyrau 1981; Moon 2001; Hildermeier, 2013: 879-899). Special rules put pressure on both sides to make an arrangement. If peasants refused to pay for land, they could get a small free "beggar's share". If nobles did not want to wait for the arrangement set, they could renounce 20 percent paid by peasants and get 80 percent paid by the state immediately. The "beggar's share" is important for it allowed peasants to leave agriculture though emancipation was to provide every rural household with a land allotment; therefore, in the non-black-earth districts, many peasants previously engaged primarily in cottage industry or migrant labor used this opportunity (Gorshkov, 2018).

In 1856 and 1861, Alexander II's appeals to the nobles and serfs can be considered as a fascinating modern political approach to solving problems. In the political system called "autocracy", the autocrat asked the sides involved to discuss the local regulations instead of declaring the rules "from above" (Merl, 2018). Such an "enlightened" procedure was not possible under the Soviet rule: Stalin, Khrushchev and Brezhnev' decisions did not take into account the opinions of the rural workforce. With the local contracts between noble landowners and peasant communes entering into force after 1863 , the former serfs could become peasants. In the land communes, rural households used to work individually, now they got the right to freely develop farming. When the loan was repaid, they became proprietors of their land allotments.

Emancipation in many parts of Europe was decisive for strengthening family farms for it distributed the land in communal use to consolidate the land of family farms. Rural households without sufficient land left agriculture. The result was twofold: the newly independent and free peasants got enough land to start a viable farm and improve the technology of production by investments; at the same time the market demand for agricultural products increased for those who left agriculture had to buy food in the market. Thus, due to emancipation, those who got the full farmstead won better opportunities to increase production: the distribution of previously communal land and stall-feeding in the summer provided them with more arable land. Better crop rotations and the use of animal fertilizers allowed them to increase yields. Thus, emancipation in the German countries led to 
60 the "agricultural revolution" ensuring necessary food for industrialization - fewer peasants could feed more people and increase incomes.

история The situation in Russia in the mid-1gth century was significantly different. Even in 1913, only 16 percent of the population (in Germany -49 percent) lived in the cities, and the need for labor outside agriculture could still be satisfied by migrant labor from the countryside, although communal households were restricted in migration. The industrial development started only in the late 1880 s, and the textile and coal sectors industrialization affected mostly rural areas by offering additional sources of seasonal incomes to households. The "agrarian crisis" of the 18 gos was a crisis of overpopulation due to the rapid population growth, primarily in the central black-earth regions. Here, due to the fertile soil and drudgery under serfdom, rural households were primarily engaged in agriculture with the limited tradition of migrant labor or cottage industry. The rapid growth of population reduced the average share of land; however, the problem was not the size but rather the use of land for grain was not a highly valued agricultural product.

The Russian historiography was concerned mostly with the question whether peasants won or lost land due to emancipation. This controversy did not pay attention to what the peasants won: land property. The result of emancipation was only leveling the allotments. The majority of peasants got enough arable land (about 6 hectares - more than the average Germany) to produce agricultural surpluses for the market, which was the most important result in the long run. After a few decades, the value of land was well above the price the peasant paid, especially in the black-earth regions (Hoch, 2004). At the end of the century, it was out of question that the peasants were the winners of the reform: while in the 1860s the arable land was divided roughly in half between nobles and former serfs, in the following decades, it was the peasantry that increased the share of land. Already in 1900,80 percent of the arable land was property of peasant communes or peasants, if taking into account the land leased from the nobles - about 90 percent.

By the end of the 19th century, rural underemployment and insufficient demand for agricultural products still hindered intensification of the Russian agriculture. The increase in need for labor outside agriculture did not cope with the high rural birthrate, and still about 80 percent produced at least a part of their food. Therefore, there was no basis for the development of viable peasant farms in the center of Russia. There were no "peasants" in the contemporary meaning of the word in the central non-black-earth regions of Russia before 1914. While rural households in general earned incomes from different activities, in the non-black-earth regions only very few got main incomes from agriculture (Gorshkov, 2018). With differentiation increasing, two groups appeared: those earning money primarily from migrant labor, handicraft or cottage industry, and those earning mon- 
ey mainly from agriculture. The term "peasant" should be used only for the latter. Among those earning money not from agriculture, only a few had already stopped working on their land. Those focusing on agriculture often wanted to extend their production by leasing land. To allow some households to get main income from agriculture, the market demand for agricultural products had to grow. The path for the majority of rural households was "proletarization" - a process of upward social mobility under the miserable living conditions in the countryside as compared to the city (Merl, 199ob).

Modernization of agriculture normally begins under the pressure from outside: intensification starts when the urban demand for food increased. Mechanization is a reaction to the outmigration of cheap labor. Horticulture, animal husbandry and industrial crops not only need a higher labor input, but their products are sold at more attractive prices than grain, which contributed to the growth of per-capita incomes. The increasing urban demand allows peasants to specialize in agriculture and improve technology. Modernization by intensification (crop rotation, developing animal husbandry, growing labor intensive industrial crops, use of better and more expensive seeds) is possible without mechanization, and under the rural underemployment primarily allows a better use of the available workforce. While animal traction power and cheap labor (due to the hidden unemployment) are abundant, there is no need for expensive mechanization. The cost calculations of the German agricultural concessions in Russia before 1933 prove this (Schmieder, 2017: 109-111): mechanization normally takes place when the rural labor is not enough and, thus, more expensive than the use of mechanical equipment. With the investments in industrial inputs (machinery, fertilizers, tractors), the rural labor productivity increases significantly together with the demand for qualified and trained workers. Thus, industrialization was a basic precondition for the agricultural modernization in Russia - it increased the urban demand for food and gave incentives for outmigration.

In the 1870s, the slow but steady growth of the grain yields started (about 1 percent per year). However, while the input of seeds and fodder was the same, 30 percent over in 30 years meant net growth providing more grain for export and even a slow increase in the per capita consumption (Gregory, 1982). The drive for the agricultural demand before 1914 was primarily exports and not the urban demand. The increasing global grain prices were a strong stimulus for the Russian agriculture during most of this period.

\section{Stolypin reform}

In the late 19th century, noble and non-noble estate proprietors started to modernize agriculture by introducing new crops (such as sugar

\section{S. Merl}

Agricultural reforms in Russia from 1856 to the present: Successes and failures in the international comparative perspective 
62 beet) and/or processing. In the early 2oth century, this modernization led to the peasant unrest for it questioned the post-emancipation история compromise between peasants and land owners: the use of machinery meant that the estate owners hired less agricultural workers thus many rural households lost additional seasonal incomes. Moreover, intensification of production violated the traditional peasants "rights" to use estate meadows as pastures and nobles' forests (Schedewie, 2006; Merl 2017b). From the 18gos, some peasants, especially in the less densely populated south-eastern borderlands, tried to improve their agricultural production by using machinery imported or domestically produced (for instance, by the Volga Germans). The number of those interested in modernizing their farms was growing, but they still were a minority among rural households.

The pressure to complete emancipation by an additional agrarian reform was determined politically - by the peasants' participation in the revolution of 1905 . However, the reform was primarily due to the new requirements of agriculture after the industrial "take-off". The reform draft was ready in the 18 gos to support modernization of agriculture with such measures as land consolidation, land settlement, developed crop rotation and a better quality of seeds and cattle breeds. The request for land consolidation was "from below": some peasants wanted their land to be separated from land communes as khutors and otrubs. Therefore, the Stolypin reform did not fail, and its limitation to land privatization is misleading. Only the political intention to create strong peasant family farms to support the autocracy failed. The peasant lack of interest in private land property was determined by their traditional legal perception of private property as a part of serfdom, i.e. property was an abstract legal category for them. Peasants used to work on the land individually regardless of its legal status. Therefore, the Bolshevik nationalization of land in 1917 was not a rupture for them on the path to peasant family farms (Merl, 1999).

The importance of the reform is evident if we consider it through the activities of all state agencies in agriculture. To stabilize peasant farms, in 1905 , the state started to participate in the agricultural modernization and to support peasant agriculture significantly. Agricultural machinery was provided, especially in land-rich regions. Regional self-governments (zemstvos) played an important role - employed agricultural specialists and regularly showed agricultural improvements and new machinery at the regional exhibitions. The Russian Ministry of Finance followed the German model (Preußenkasse) and founded in 1905 a special state foundation to support agricultural credit cooperatives. What was important in the long run is that the state laid the foundation for training agricultural specialists at universities. Agricultural technical schools were opened and the training of agrarian scientists started. The graduates found jobs in newly opened agricultural and zemstvo administrations.

The state support gave a strong impulse to rural credit cooper- 
ation. In just a decade, in 1914, every second rural household was a member of rural credit cooperatives. They provided loans on good terms, ensured that the state bank inspectors did not disturb the peasants. The inspectors reported annually on the development of cooperative finances providing at the same time valuable information on how the peasants reacted (Merl, 2008). Credit cooperatives managed to overcome the peasants' skepticism. The state control ensured that cooperative credits were not gifts to people in need, which was previously typical for cooperatives founded by the intelligentsia, and were to improve agricultural production. Measures against those who did not repay loans showed a paradox: they strengthened the peasants' trust in new cooperatives, and the inspectors' control even encouraged them to make small deposits.

By organizing the rural trade and by processing the agricultural raw materials, credit cooperatives put an end to the preindustrial monopoly of usurers, private traders and proprietors of processing plants. Credit cooperatives provided peasants with production inputs (seeds, fodder, fertilizers, farm equipment) at reasonable prices and consumer goods (including kerosene and salt). The state inspectors' reports show to what extent the market access at reasonable prices was necessary for Russia before 1905 (Merl, 2008; 2013). Thus, the rural underdevelopment and backwardness in Russia were determined primarily not by "exploitation" but by the preindustrial weakness of the rural markets.

To consider the peasant thinking is difficult for most of the sources available were written by the intelligentsia and reflect its interpretations. The intelligentsia defined peasants as uncivilized and unrational. Even the autobiographical works of Bonch-Bruevich, Rubakin and others presented peasants as to be civilized based on the conviction that to become human beings they had to leave their peasant surrounding (Herzberg, 2013). Despite the contemporary views, there was no impoverishment though the majority of rural people were poor and had little free money for consumption (Hoch, 1994). Not the "capitalist exploitation" was the main problem as Lenin and the Bolsheviks believed. On the contrary, the poverty of most rural households was rather a pre-capitalist phenomenon determined by the impossibility to find work/to be "exploited" (Merl, 1985b).

\section{"Turning to the village" (1921-1928)}

After the interruption of the land redistribution under the peasant revolution of 1917-1918 and war communism, the New Economic Policy returned the market and co-operatives to develop agriculture based on the findings of the Russian agrarian science and education of the world's level (Bruisch, 2014). Zemstvo statistical data was the best basis for studying the peasant agriculture and developing rational meas-
63

\section{S. Merl}

Agricultural

reforms in Russia

from 1856 to the

present: Successes

and failures in

the international

comparative

perspective 
64 ures for the first five-year plan. The theory of peasant economy was introduced by Aleksandr Chayanov (Shanin, 1972). In 1924, the Bolsheviks adopted a new agrarian program focusing on the most acute rural problems such as underemployment of the rural workforce. Litsom $k$ derevne was to create and promote new jobs in the countryside. Industrialization based on modern technologies was to be capital-and not labor-intensive; therefore, it was not expected to create many new jobs for the untrained labor (as industrialization in capitalist countries). The rural underemployment was to be reduced by helping peasants to create new jobs in processing and handicraft and to intensify agricultural production. Hired labor and land lease were legalized (Merl, 1981; 1993: 144-176). To promote agricultural technologies, many Stolypin measures were prolonged, for instance, land consolidation in the form of khutors and otrubs, scientific crop rotation and improved seeds. This policy was a necessary step to create viable peasant family farms and was accompanied by the state support of agricultural investments, credits and mechanization. The peasant reaction in the mid-1920s was very positive: a significant part of rural households, often about 10 percent in the region, wanted to improve their agriculture. Based on the policy name - "Litsom $k$ derevne" - they were called "kulturniki" and tried to modernize their agriculture with the state support (Merl, 1981; 1993).

The experts calculated the real hidden unemployment in the mid1920s: about 10 million of the able-bodied rural population were not needed for the agricultural and handicraft production. As the total employment outside agriculture (urban workers) was also about 10 million, this was a huge number (Merl, 1993: 270-276). Any rapid mechanization of agriculture would reduce the labor demand and set labor free, thus, exacerbating rural underemployment (Volf, 1928).

Due to the ideological fight between the leading party members rather than to its failures, the Litsom $k$ derevne policy was implemented only until 1926. By that time, agricultural cooperatives became a part of the state procurement system. They bought up grain far from the railway stations and at the lowest prices, which determined peasants' mistrust in cooperatives and reduced the amount of grain in the market (Merl, 1981). The disfranchisement of the socalled "petty capitalist" at the 1927 election to the rural soviets affected only the kulturniki, and the "individual taxation" destroyed them: the taxed were often higher than their total income (Merl, 1981; 1993: 177-360). Thus, the forced collectivization aimed at destroying the kulturniki who successfully developed their farms in the 1920 s (Merl, 1990a).

In 1927, the peasant-worker relations significantly worsened due to the privileges given to workers and not to the "middle" peasant. The October manifest contributed to the situation for it ignored the peasant decisive contribution to the revolution (Merl, 1993: 442-486). The peasant bad feelings were also determined by the "price scissors", un- 
favorable agricultural-industry terms of trade: compared to the pre1914 period, agricultural products prices were much lower, while the prices of industrial goods bought by the peasant were much higher. Unlike urban workers, in the mid-1920s, rural households were below their low pre-war level of consumption. In the winter of 1927-1928, their miserable incomes under the state pressure to create collective farms explain why a lot of peasants dreamt of becoming workers with monthly salaries. Male peasants preferred to join state farms with monthly salaries to collective farms distributing an uncertain "profit" only at the end of the year (Volf 1928; Merl, 1985a; 1993: 453-482).

Stalin's belief that due to the small peasant farms the grain marketing was reduced by half in the 1920s does not stand a critical examination for the figures presented were falsified. They presented consumption and not sales outside the village: the grain marketed by peasants and consumed by rural households in the non-black-earth regions was not considered as marketed although it was often transported for hundreds of kilometers (Merl, 1981; 1993: 277-334).

The state support of peasants was quite successful in the late 1920s. The agricultural experts in the Soviet administration were sure that the remaining defects in the peasant production would be overcome and expected a significant growth in yields. In the first five-year plan, they suggested to increase peasant yields by introducing an obligatory "agronomical minimum" - a progressive crop rotation and the use of selected seeds. The state would provide financial support to allow the poorest peasants to fulfill the requirements. However, when Stalin introduced this minimum as obligatory, he stopped the financial support and required from peasants a "tribute" to industrialization (Merl, 1985: 166-213; 1993: 393-407; 2016). In the late 1920s, about 10 percent of kulturniki in most agrarian regions were a good basis for the further successful agrarian development in the 1930s. For the expected final results, the country needed (besides the outmigration of rural workers due to industrialization) about a decade. In the late 1920 s, the rural sector was certainly backward, but it was on the path of the European patterns.

\section{Search for a viable socialist agriculture (1929-1987). Stalin's collectivization}

The final version of the five-year plan for agriculture was still a plan to develop peasant farms by improving their agricultural technologies to increase yields (Merl, 2016). Many experts warned that the simultaneous collectivization and industrialization would have disastrous consequences: due to the rural overpopulation, the forced collectivization would lead to social destabilization in the cities and starvation in the countryside (Merl, 1985a; Volf, 1928). The experts preferred a mechanized agriculture based on the national production of agricul-
S. Merl

Agricultural

reforms in Russia

from 1856 to the

present: Successes

and failures in

the international

comparative

perspective 
tural machinery. Only at the end of the first five-year plan, the Soviet industry would produce tractors and farm implements necessary for the starting agricultural mechanization.

Stalin's turn to the forced collectivization in October 1929 was abrupt and not based on the expert estimates. He ordered the worker brigades collecting grain in the countryside to start collectivization without considering how these collective farms would function. Even in December 1929, there was only pressure to speed up collectivization: it was to take regionally not more than two years. To force the frightened and reluctant peasants into the collective farms, Stalin ordered to destroy the so-called "kulak farms", arrest their heads and deport their families. Only after months of the forced collectivization and destruction of agricultural productive forces, in March 1930, a statute on collective farms was published, which was determined by the peasant women riots (babie bunty) against expropriation of cows. Stalin understood that the riots put his rule in question and acted immediately: in the statute, he allowed the former peasants within the collective farm to have a private plot and one cow. Stalin remembered how dangerous the situation was and in 1933 , he mentioned a previous "minor misunderstanding" of the female peasants (Merl 1990a: 257-260).

Collectivization was based on the vague ideological expectation that the large-scale farming would be superior to the small-scale farming. However, in agriculture, there is no "eternal law" of superiority of the large-scale over the small-scale production, as Marx believed (Krebs, 1983). The scale plays a role only in the plant production when the use of machinery is possible. In the 20 th century, many peasants successfully mechanized their farms: western plants produced agricultural machinery that could be cost-effectively used by small farms. In the animal husbandry, the priority of the largescale production was even less evident (it still suffers from diseases and determines environmental problems).

Collectivization did not take into account the rural underemployment. Collective farms became such a huge failure primarily due to the fact that they had a huge workforce without sufficient productive work for it. State farms hired seasonal labor during the harvest, while kolkhozes had workforce during the whole year, no matter if there was work or not. The possible labor input decreased dramatically under collectivization, which was only to a minor extent a consequence of the lesser labor need at larger enterprises. The possible labor input in the animal husbandry reduced in half as the livestock did not survive collectivization. Some productive animals were slaughtered by the peasants in protest against the menacing expropriation of collectivization, but most of the cattle and workhorses died due to the lack of fodder at collective farms for the state confiscated all stocks. The previously regionally important peasant incomes from handicraft and cottage industry disappeared for the state confiscated the necessary raw materials. 
In the 1930s, most able-bodied members of collective farms were provided with workhours just for 100 to 140 days a year (Merl, 199ob: 150-158). By forbidding any non-agricultural production at collective farms, Stalin made the situation even worse (the collective farms' workforce was not paid). If the collective farm members could process agricultural products or do some handicraft production, they would immediately stop working unpaid in the fields (Merl, 1990a: 327-417). In the country suffering from rural underemployment, mechanizing of agriculture without alternative occupations was a death sentence for many "unnecessary eaters". Unlike 10 million workhorses that could not be replaced by tractors until the late 1930s, more than 6 million people, who died under the 1932-1933 famine, were not needed for either agriculture or industrial production (Merl, 1995).

The forced collectivization proved to be destructive and led to the famine of 1932-1933. Stalin denied the famine and successfully tabooed it (which lasted until 1988). The fact that he radically changed his approach to agriculture and the "kolkhoz system" prove that he was well aware of the famine threatening his rule. While he officially blamed the peasants of sabotage, behind the scene he made concessions to the peasants and ended the arbitrary expropriation of grain. When introducing the kolkhoz system, Stalin partly listened to the experts (Davies, 2004: 250-331). This system became effective at the end of $193^{2}$ (and worked until the enlargement of the collective farms in the late 1940s) as based on the compromise between the peasant interest in survival and the state interest to get a high share of agricultural production (Merl, 1990a; 2002b).

The basic idea of the kolkhoz system was the return to the tax in kind (hidden in the symbolic payment covering less than 20 percent of the production costs). The tax became effective in 1933 when claimed the fixed numbers per hectare and per animal. It also confirmed the right of all households within the collective farm to have a private plot. In the mid-1930s, for a short time the state even provided credits to help households to have a strictly limited number of animals (one cow, one pig, some poultry) (Merl, 1990a: 260-280). The kolkhoz system also introduced the so-called "advance payment": during threshing 10 to 15 percent of the grain was to be distributed among the collective farm workers according to the number of labor-days until the harvest, despite the fulfillment of the state delivery plan. This "pre-payment" in kind was the only thing the workers got for their labor-input at the collective farm. At the end of the year, usually nothing was left for the "final" distribution of the profit. The pre-payment guaranteed the workers at least some grain from the collective farm as fodder for their animals or poultry (Merl, 1990a: 327-417).

The failure of collectivization to provide the population with necessary food forced the majority of the Soviet people to keep the parttime participation in agriculture to produce some additional food. Due to the miserable food situation outside the big cities, in 1934, Stalin
67

S. Merl

Agricultural

reforms in Russia

from 1856 to the

present: Successes

and failures in

the international

comparative

perspective 
granted small land plots to workers and employees including the state farm workforce. These plots became the backbone of the Soviet peoистория ple survival. The obligation introduced by Stalin to produce potatoes on these plots and to deliver a part of the harvest to the state as a tax in kind was of great importance for survival of the civil population during the World War II. Not collectivization kept people alive, as is argued today, - on the contrary, the failure of collectivization did (Merl, 1990a: 257-326).

The kolkhoz system divided production into two differently organized spheres: the large-scale collective/state farms produced grain and some industrial crops (flax, cotton, sugar beet), while the tiny private plots focused on animal husbandry, potatoes, vegetables and fruits and used primitive farm implements. Stalin's collective farms had nothing in common with the agro-industrial complexes including not only all aspects of production but also processing, storage and sales of agricultural products. At the end of 1929, some agricultural experts like Nikulikhin dreamt of such enterprises, but the state never accepted such huge investments necessary for these projects (Merl, 1985b: 365-36g).

According to the "Barsov-balance" (Barsov, 1969), collectivization failed to make a significant tribute to industrialization. Agriculture's contribution was significant in 1926-1927 due to the "price scissors" (Merl, 1981); compared to it, the tribute under the first fiveyear plan was very moderate for the peasants could sell some products at high prices at the local markets out of the state control. This offset the state investments in agriculture by importing not available tractors to substitute workhorses dying at the collective farms. After 1933, the tax in kind ensured a significant tribute of agriculture for the state got grain and agricultural products without paying the producers. Thus, it was the urban workers who bear the costs of industrialization between $193{ }^{\circ}$ and 1933 - their wages lost half of their value in 1930-1931. Collectivization was the most damaging element of the forced industrialization (Hunter, Szyrmer, 1992).

Considering labor, the forced collectivization was also harmful for industrialization by making the previous rural underemployment a permanent feature of the industrial work. Despite the severe shortage of well-trained industrial workers, Stalin ordered to retrain at least 25,000 for the leading positions at the collective farms. Outmigration (rather flight) from the countryside was temporarily very high. The industry complains about the "lack of labor" in the fall of 1930 did not show the real shortage. The reduction of salaries encouraged enterprises to "hoard" cheap labor for the few days of the peak labor demand. The low salaries determined a significant decrease in the industrial labor productivity and an extremely high labor turnover. In the 1930s, the majority of the industrial workers were untrained and the labor productivity was low. The high outmigration was stopped by Stalin in 1932, when the famine started. He introduced passports 
but not for the members of collective farms, which limited their freedom of movement until 1974 .

Although the kolkhoz system provided the state with a high share of the agricultural production, this was rather a pyrrhic victory for this very system was the best way to keep the agricultural production low. The state did not pay the costs of production; therefore, its increase meant higher operating losses for collective farms. If not the destruction of the agrarian productive forces by collectivization, the agricultural production would have been significantly higher in the 1930 s. Thus, even a lower share of marketing would have meant more agricultural products for the urban population and for export (Hunter, Szyrmer, 1992). Moreover, the state prevented a possible rise in yields by force: collective farms had to produce grain on the large part of their arable land, and all attempts to introduce scientifically based crop rotation were stopped by force (Merl, 2016). With the forced collectivization, Stalin put agriculture under the state control and supported the intelligentsia's conviction that no special knowledge was necessary to run agriculture: he sent the retrained workers to command the alleged peasants. The kulturniki proving their ability to modernize agriculture were arrested as kulaks and sent to labor camps to dig Stalin's White Sea canal.

The term "collective farm" is misleading for in every aspect they were under the state command. During the key state campaigns, even special envoys "from above" commanded the local collective farms, party and state apparatus. The fiction of "collective ownership" was used to hide the fact that the collective workforce was not paid (Merl, 1990a). Stalin's mechanization did not contribute to modernization for it primarily served to control peasants and agricultural production. Tractors and machinery were not given to the collective farms but kept at the state-run machinery-tractor stations (MTS). Combines allowed to expropriate the harvested grain directly from the fields, avoiding the collective farms barns (Miller, 1970; Merl, 1990a; 2002b).

\section{Why did Khrushchev's and Brezhnev's mechanization of agriculture fail?}

Already before Stalin's death, many shortcomings of the agricultural policy were known to the new Soviet leadership which accepted in June 1953 that the results of collectivization were disastrous and changes were necessary (Transcript..., 1998; Merl, 2002a; 2011). In the fall of 1953, they significantly raised the producer prices to allow collective farms to pay to the kolkhoz workforce. The opened archives provided new information on the darker sides of Khrushchev's unstable and shortsighted decisions in agriculture with fateful consequences for the future of farming in the Soviet Union (Merl, 2002a). There are two phases in Khrushchev's agricultural policy: "liberali-

S. Merl

Agricultural reforms in Russia from 1856 to the present: Successes and failures in the international comparative perspective 
70 zation" approaches in 1953 to 1955 , and destructive approaches from 1958 (Medvedev, 1987; Popov, 1989; Merl, 2002a). By his promise to история build communism Khrushchev caused a lot of harm: by his campaigns against the private keeping of livestock and the collective farmer's plot production he hit the backbone of the decentralized additional food supplies. Finally, he was responsible for the flight of most needed people from the countryside (Merl, 2002a; Medvedev, 1987: 161-202). However, on the positive side of Khrushchev's balance sheet, there is a possibility to question the forced collectivization and industrialization (Merl, 1991): for some time, there was an open discussion between Soviet specialists, and their closer contacts with the Western agriculture restarted.

In the mid-1950s, due to the intensive contacts with the West, the Soviet Ministry of Agriculture and specialists were well aware of the fast progress of the agricultural machinery and agrarian knowledge in the West, while the Soviet Union stuck at the level of the late 1930s. Mechanization of a part of the grain and cotton production started quite early, but under Stalin it never affected the whole agriculture, especially fodder and animal production. Concerning the quality of the agricultural machinery after the World War II, the Soviet Union lagged behind not only the leading western countries, but also many of its block partners (GDR) (Jaehne, 1976: 27). Rural electrification and water supply - preconditions for the mechanization of animal production - spread very slowly to remote rural settlements (Schinke 1967: 70-72, 99). Although in the animal husbandry women were the majority of the workforce, their heavy physical work input was never overcome under the Soviet rule.

The fast progress of the agricultural technology in the West after the World War II was determined by several factors: to feed people in the developing countries, the so-called "green revolution" started, and it was based on the intensive use of the agricultural research, especially in seed and breed selection, which led to a significant increase in yields. The lack of workforce determined industrialization of agriculture - the expensive labor input was replaced by the complex mechanization of all production processes.

Soviet specialists sent to the Western countries understood how advanced the Western agricultural machinery and agrarian science were. Soviet specialists studied them and asked to import models for constructing machinery. Although this work was successful and improved either models of machinery or their production processes tested in the construction offices, most of them were never available for the state and collective farms: under the Gosplan and the Ministry for Tractor and Agricultural Machinery Construction, the Soviet agricultural machinery industry never started the mass production. Unlike Western machinery plants, it had primarily to fulfill the state plans rather than to satisfy the producers' needs or to consider their demands and proposals. It did not care whether the machinery worked 
fine or was of no use at all for agricultural enterprises. Instead of building new special plants, Gosplan often kept investment costs low and made enterprises of other industrial branches produce some agricultural machinery. Such enterprises lacked any interest in producing high quality implements, improving their production or correcting construction mistakes (especially the milking equipment suffered) (RGAE: f. 7486, o.1; Schinke, 1967: 76).

Soviet agricultural scientists were often well trained but used the old-fashioned and increasingly backward equipment at the agrarian faculties, research institutions and laboratories, i.e. the new generation of specialists could not be trained on the modern machinery. As the necessary equipment was not produced in the Soviet Union, almost every implement needed for the laboratory work was imported from the capitalist countries, a few were available from the block partners. Thus, it was increasingly difficult for Soviet scientists to keep up with the progress of the international research (RGAE: f. 7486, o.1.). Therefore, the command economy was responsible for not implementing the research findings in the work of the large-scale enterprises.

Khrushchev did not understand the need for raising efficiency by mechanization. Instead of providing every large-scale agricultural enterprise with the necessary transport and machinery to organize the production process, until the very end of the Soviet Union, almost all collective and state farms suffered from the lack of sufficient transport and machinery even for the minimal production needs, which determined huge losses of agricultural production during the harvest and transportation (Schinke, 1967: 20-28).

The lack of tractors and agricultural machinery for his virgin-land campaign made Khrushchev introduce the "harvest help" — bringing combines and transport from the southern regions to the virgin land where the harvest started later. This was considered an extraordinary measure at the beginning, but then this movement of transport and agricultural machinery between agricultural regions became routine in all state-run harvest campaigns. Later the transport of people was added - starting with the campaigns of the voluntary movement of the Party Youth - komsomotsy - to the virgin land. After that an ever-growing number of students and industrial workers was moved for the "harvest help" to the countryside all over the Soviet Union. Every year the republican authorities, for instance, the Council of Ministers and Central Party Committee of Ukraine, protested against the obligation to send part of their machinery together with the trained tractor and combine operators to the east (there was shortage of them in Ukraine too). Nobody calculated the enormous losses of this crazy back and forth movements for the national economy and for the republics (RGAE: f. 7486, o.1.). This form of the state handling of the basic means of production deprived the state and collective farms of any control of their economic results. 
In 1958, Khrushchev made the collective farms buy the old broken machinery from the MTS at the prices of new equipment for he история needed money for his space program. In 1959, due to the lack of liquid money reserves, the collective farms cut the orders of new machinery, which Khrushchev declared a proof of their having enough machinery and ordered to reduce the production of agricultural machinery (Merl, 2002a). The MTS liquidation could have ended the collective farms control by "two masters" and provided them with the machinery. However, the state agencies did not stop to interfere with the production decisions (Miller, 1970: 90-93, 165, 321-323). Although (unlike under Stalin) most chairmen of collective farms and directors of state farms were highly qualified agricultural specialists, they still (unlike heads of industrial enterprises) (Merl, 2017a) had to follow all orders "from above". The final attempt to make the heads of the state and collective farms masters of their enterprises was made at the end of Khrushchev's rule: in Kazakhstan, as an experiment, the director of the state farm Khudenko was given the full control of the farm's machinery and workforce to organize production and remuneration. The experiment was successful but was stopped as questioning the need of the state apparatus. Khudenko was arrested for corruption and died in prison (Merl, 2019; RGAE: f. 7486, o.1).

By the MTS liquidation and attempts to build communism Khrushchev caused the out-migration of those needed for implementing a real reform based on technological innovations. In 1958, many tractor operators left the countryside for they feared to be returned to the miserable status of the collective farm member. Then those who dreamt of returning to private farming left. Thus, by the ideas of the communist agriculture Khrushchev destroyed the "peasant" consciousness in the Soviet countryside. Finally, many qualified heads of the collective farms resigned, who wanted no longer to fulfill the crazy orders "from above" (Merl, 2002a: 212-225). Under Khrushchev, the local party organizations started to successfully get rid of their unpopular responsibility for weak collective farms. After turning such collective farms into large state farms, as if a "higher" form of property, they could not be blamed for their economic failures. The new state farms rarely managed to be economically successful, but the direct control of the ministry made the state cover their losses (Wädekin, 1969; RGAE: f. 7486, o.1).

After Brezhnev became the General Secretary of the Party, there were radical changes in investments. The 1965 Plenum of the Central Committee gave priority to the investments in agriculture. Its share in total investment rose from 11 to 12 percent under Stalin, to 14 percent under Khrushchev, and to about 20 percent in the 1970 s (Narodnoe..., 1987: 318). Under the outmigration caused by Khrushchev, just those better qualified and more competitive workers left agriculture, who were urgently needed for mechanization and automatization of the production processes, which partly determined 
the outcomes of Brezhnev's policy of capital investment. In general, the remaining rural workforce lacked the necessary qualification and knowledge, the majority was only capable of manual labor (Wädekin, 1976: 212-215). Brezhnev's failure is even more evident in the perspective of the agricultural labor productivity. While mechanization in the capitalist countries led to the fast growth of productivity, it hardly had any effect in the Soviet Union (Wädekin, 1976: 212). Despite the capital input, the labor input in agriculture did not decrease. Although the number of those employed in agriculture decreased by 35 percent from 1959 to 1970 (from 33.2 to 21.8 million people), the number of labor days was reduced just by 2 percent (Wädekin, 1976 : 202-203). Thus, the only effect was the reduction of the rural underemployment to zero.

Despite the large-scale agricultural structure, the share of the employed in the primary sector (agriculture and forest) reduced from $195^{\circ}$ to 1980 only from 48 to 20 percent, while in West Germany with its small-scale agriculture the corresponding numbers were 16 percent in $195^{\circ}$ and 5 percent in 1980 . The Soviet numbers were extremely high in the international perspective. However, ever-growing numbers of students and workers were sent for the "harvest help" to the countryside. The share of this additional labor in the total labor input in agriculture increased from 0.6 percent in 1960 to 3 percent in 1974, and these numbers do not include soldiers and transport operators sent every year from the army to the state harvest campaigns (Wädekin, 1976: 200-201).

Since the mid-1950s, the main goal was to increase efficiency and to reduce the agricultural production costs. On January 3, 1968, the minister of agriculture Matskevits informed the Politburo to what extent this aim was not achieved. Together with the Soyuzselkhoztech$n i k$, he proposed a plan of the whole mechanization of the agricultural production for Kosygin and Brezhnev. Matskevits considered the efforts of his ministry for twelve years to compare Western and Soviet agricultural technologies and to put new machinery constructions into mass production, and identified the deficiencies of inputs produced in the Soviet Union as compared to the technologies of the leading capitalist countries. He complained that the final construction proposals of the urgently needed machinery were never put into mass production due to the lack of raw materials or other priorities of the Gosplan. Moreover, it was not possible to stop the production of outdated machinery for the industry had to "fulfill the plan". The increasing use of harvesting combines often affected the yields negatively for the misconstruction of combines led to significant crop losses in the fields. Industry was not interested in the changes required by the Ministry of Agriculture (RGAE: f. 7486, 0.1).

Brezhnev's investments determined the steadily increasing costs of the agricultural production, while its results were extremely poor regarding the increasing efficiency. Tikhonov calculated that the huge
S. Merl

Agricultural reforms in Russia from 1856 to the present: Successes and failures in the international comparative perspective 
74 investment in irrigation annually increased the yields just by 1 percent. The comparison with the European Union's (EU) agriculturистория al policy ensuring the growth of agriculture's efficiency reveals the causes of such failures. Unlike the Soviet Union, in which per unit costs of agricultural production increased significantly in the 1960 s and 1970s, the EU kept the production costs stable therefore, to make profit, the producers had no alternative than to increase productivity and reduce per unit costs. The EU producers achieved this goal successfully and replaced the expensive labor by capital input. Large subsidies of the EU served to increase not only productivity but also agricultural production. In the Soviet Union, the subsidies primarily kept the consumer prices at the fixed level below the costs of production, which required increasingly more money for there were no limits for the production costs. The state guarantee of the minimum wages for agricultural workers also did not stimulate the growth of efficiency. Most large-scale enterprises worked with losses but received state credits, which were written off from time to time. As the state decided on all inputs, enterprises had no chance to choose anything that would have the best effect for their efficiency. Thus, the state command in agriculture prevented any effective pressure to reduce production costs.

Although the increase of the Soviet agricultural producer prices from 1953 to 1955 aimed only at paying some money to the previously unpaid workforce of the collective farms, state officials were concerned about the increase in costs and looked for compensations. As the possibilities to reduce the net payment for agricultural products were limited, they decided to set higher prices for the "improved" inputs. The industry replaced the previous tractors and machinery by new models that were in general much more expensive but often of the same bad quality as the old models, which increased only the costs of production but not the efficiency (Jaehne, 1981: 59-61). For instance, from 1965 and 1975 , the prices of tractors increased by 25 percent, of agricultural machinery and other inputs - by 50 percent. By the higher prices of new models, the industry compensated its losses from producing the price-fix old models and followed the myth of no inflation in the Soviet Union. Thus, the state command was responsible for the steady increase in input prices and its consequences for the agricultural production. The price policy for inputs followed some strange guidelines and did not reflect the real production costs. For example, unlike the western countries, the prices of wheeled tractors were higher than the prices of caterpillar tractors (Schinke, 1967: 18-20, 84-85; RGAE: f. $7486,0.1)$. The high share of caterpillar tractors contributed to the losses of the collective and state farms for these tractors could not make up for the general lack of transport and deprived the enterprises of the possibility to use tractors throughout the year.

The poor quality of the agricultural machinery produced in the Soviet Union explains the failure of mechanization. The agricultural 
enterprises had to buy what the industrial enterprises produced and what the state apparatus ordered. Many tractors did not manage to work until the end of the producer's guarantee (RGAE: f. 7486, 0.1). For special agricultural activities such as harvesting of potatoes or fodder production hardly any machinery was produced in the Soviet Union - it was imported from the GDR and other block members (Schinke, 1967: 66-68; RGAE: f. 7486, o.1). No machinery was provided for the production needs of small plots (RGANI: f. 5, o. 88 (1982). Heavy tractors damaged the soil; agricultural equipment often could not be used to the chronic shortage of spare parts. Soviet machinery not only broke down more often than the "capitalist" ones, but also needed days if not weeks to be repaired during peak times of sowing and harvesting. Spare parts including tires were always in short supply; quite often there was no fuel to use tractors; fertilizers managed to get only to the railway stations and, being unpacked, were spoilt in the open air (GAYO: f. 272, 0. 249).

The state-run campaigns additionally reduced the agricultural production efficiency. After Stalin started such campaigns in 1928, they never stopped. The seasonal campaigns were widely covered by the mass media: preparations of spring sowing and repairs of agricultural machinery, preparations of harvesting and state procurement, after the World War II, there were also campaigns to provide transport, fuel, spare parts and people as the "harvest help"; preparations to feed the cattle over the winter and other activities within the "socialist competition", after which thousands of the best workers were awarded with prizes and their names appeared in the media. The prizes were given for the production results hardly changing under the Soviet rule and quite poor compared to the western agriculture. Crop and milk yields in the Soviet "industrialized" agriculture were at the level typical for the pre-industrialized countries (about $2000 \mathrm{~kg}$ of milk per cow in the 1970s, while in the West - 4000-5000 kg). The "socialist competition" implied that the increase in production would be determined mainly by the labor input, which contradicted the very idea of the automatic production and complex mechanization.

The campaigns revealed the scale of mistrust to both local administrations and heads of the large-scale agricultural enterprises considering their independent activities. Moreover, the campaigns showed weaknesses of the command economy: the catastrophic scarcity of necessary inputs in agriculture and dysfunctions of the official system of agricultural supplies. Without the campaigns, the industry would have provided even less inputs and would not have taken into account the changing requirements of the agricultural year.

One of the main challenges was the lack of the qualified personnel in the countryside: people kept leaving it, which meant the waste of money for training together with the waste of money for producing machinery of poor quality. The MTS problems of person-

\section{S. Merl}

Agricultural

reforms in Russia

from 1856 to the

present: Successes

and failures in

the international

comparative

perspective 
nel outflow and insufficient salaries were described already in 1938 (Merl, 2016). Despite never-ending complaints, these problems were история never solved in the Soviet period (RGAE: f. 7486, o.1). Most people trained and sent to the agricultural enterprises soon quit their jobs. From those trained from $195^{\circ}$ to 1965 only 25 percent were still engaged in agriculture in 1967 (Schinke, 1967: 26-28). The satisfaction with jobs in agriculture was very low. Starting from Stalin, the regime never stopped to make the specialist a scapegoat for all deficiencies of the state-run agriculture. For a long time, salaries of specialists in the countryside were extremely low and living conditions were unbearable. Tractor and combine operators suffered from the lack of work during long winters: they made good money in the agricultural season, but in the rest of the year their incomes were too low. As trained workers they could easily find better jobs in the cities (Merl, 199ob; 2016). Brezhnev's measures to improve their living did not change the situation much, and the specialists' outflow was still high. As a result, the number of tractor and combine operators in agriculture increased less than the number of tractors and combines (Jaehne, 1981).

There is no reliable data on the complex mechanization that started only in the 1970s. The official statistics considered only large-scale enterprises, although a large share of livestock, vegetables and potatoes were produced by personal subsidiary plots. The statistical data showed successes: the complex mechanization of the cattle production in the large-scale enterprises increased from 9 percent in 1970 to 42 percent in 1980 and 68 in 1990. Mechanization of harvesting grain, sugar beet and flax finally reached 90 percent, while of potatoes - just 36 (Selskoe..., 1988: 413; 1995: 41]. Mechanization of the fodder harvesting was so low that no data were provided (Schinke, 1967: 66-68). However, the available data does not describe the quality and scale of mechanization. It was quite typical that the registered mechanized equipment was not used for a long time due to repairs and lack of spare parts (Schinke, 1967: 35-37). Moreover, the "complex" mechanization in general affected only a part of production due to many limitations such as transport, qualified workforce, quality of the needed inputs, missed optimal timing, great losses caused by the harvest machinery. Anyway, even with the part of work being mechanized, a lot of manual labor was still necessary, which explains a very slow economic progress from 1975 to 1985 . While in the industry 51 percent of workers used machinery or automatic processes in 1985 , only 24 to 29 percent workers did the same at the collective and state farms (11 percent in 1965 and 20 percent in 1979). In agriculture, even in 1985 still 69 to 73 percent of workers were engaged in manual labor, sometimes related to machinery (Jaehne, 1981: $57^{-58}$; Narodnoe..., 1987: 109]. The data proves to what extent the statistical successes of the complex mechanization were just new "Potemkin's villages". 


\section{Making the producer a "master" of his fields again: from 1987 to the present}

After the obvious failure of Brezhnev's approach to the increase of efficiency and yields of the agricultural production by huge investments in machinery and social sphere, under the perestroika, the need to finally solve agricultural problems by the radical policy changes was admitted. The idea was to return more responsibility to the agricultural producer so that he would decide on how to fulfil the state production requirements. In the Stavropol Region, Gorbachev promoted a "new" form of labor organization - the contract team or brigade that takes on the production commitments and gets the necessary means of production to organize the production on its own responsibility. Stalin already in 1935 successfully introduced a similar form for producing industrial crops such as sugar beet: the zveno was a small group of mainly women-workers responsible for all steps of production (Merl, 199ob: 207-233).

In 1987 , the campaign propagating the contract labor organization nationwide (GAYO: f. 272, o. 269, d. 1) started the new radical changes in the system of agricultural labor. At the beginning, the campaign brought little changes for local administrations, agro-industrial complexes $(A P K)$ and most heads of agricultural enterprises feared to lose control of the workforce and means of production. Their resistance became a driving force of the more radical reform.

When in 1988 meat and dairy products disappeared from the state shops, the need for the political action became evident and the ideas of the "radical reformers" got support. There was also some pressure "from below": some managers really wanted to become masters of production. In 1989, first land-leasing and creating "fermer" farms were promoted (GAYO: f. 272, 0. 269, d. 247, 255). The US-term for peasants (fermers) was chosen to clearly separate from the state-command agriculture. The reformers were convinced that agriculture could not feed the Soviet people because collectivization had turned peasants into wage-workers without peasant consciousness or understanding of all production processes. The reformers believed that "free labor" would be superior to "wage labor" as incapable to ensure the necessary connection to the land. Thus, only making the agricultural producers masters of the land was believed to overcome the food crisis.

The $A P K$ and the vast majority of the state-farm directors and collective-farm chairmen (the new "land-owners") continued to sabotage the reform by providing the fermers with the land not suitable for production. In the early 1990s, the reformers believed that the large-scale enterprises had to be divided and their land distributed among the agricultural workers. Some republics adopted laws on private farming. When Eltsin came to power, he issued a decree on the reorganization of farms and bankruptcy for those working without profit.
$7 \%$

S. Merl

Agricultural

reforms in Russia

from 1856 to the

present: Successes

and failures in

the international

comparative

perspective 
The idea to provide every worker of the state and collective farms with about 4 hectares of land under privatization was not thoughtout well but was supported by many Western advisors (Sikor, 2017). In 1992, the strong movement to become fermers started, but the average size of the land they got was only 40 hectares. There were little chances to get more arable land in the 1990s, for the State Duma did not adopt the article of the Constitution on the private land. 40 hectares were too small to start a viable peasant farm taking into account the farming technology in the early 199os. Small private farming would have been a feasible concept only after Stalin's death, when the countryside was still extremely poor.] Agricultural machinery and scientific knowledge proved that only the capital-intensive farms could withstand the international competition. In the former GDR with the more intensive production, the average size of new private family farms was 130 hectares (Merl, 2017c). According to the more extensive production in most parts of Russia, the required average size of the private farm had to be from 500 to 1000 hectares (except for the farms producing special crops or organic production). Such a private farm required special qualifications and readiness to take risks. Even in East Germany, only a few households that got their land back wanted to start private farming. Thus, the majority of the large-scale enterprises survived after fundamental changes in their formal status and adapted to the new conditions (Merl, 2017c).

Most contemporary researchers believe that Russia did not produce enough food for its population. To what extent this was a misconception became clear after the Gaidar reform in 1992. The end of the command economy and state consumer prices strongly affected the consumer market. When the desired industrial consumer goods suddenly became available, many people preferred to buy cars, furniture, electronic devices and computers instead of meat, which determined a decline in the food demand, especially expensive meat products. Thus, it became evident that until 1991 there was an artificial overconsumption of meat products.

The 1990s were not a good time for the reasonable fundamental reform. The decline of the Russian agriculture worsened by the loss of access to the urban markets due to the food imports sent to Russia as a "hunger help" and general problems of the transition from the command economy to the market (legacy of collectivization). The Russian food sector could not compete with the western imports, which proved that the key problem of the Soviet agriculture was not so much the amount of agricultural production as underinvestment in the agricultural sector: outdated and broken technical equipment in processing, lack of adequate transport, storage, refrigerating and packing facilities were the features of the Soviet rule. In the today perspective, it is obvious that the Soviet Union suffered from the agricultural overproduction. 
The reformers' plan that the high demand and attractive prices would create conditions for the agricultural modernization did not correspond to reality. Moreover, the producers suffered from the loss of access to the domestic market. Many urban markets were full of the western food-help to "prevent famine". In 1992-1993, in most regions the mafia structures emerged and earned money by offering "protection" (krysha) to those producing, transporting and selling products. Most fermers were totally excluded from the domestic market and could sell their products only at the roads next to their villages (Pallot, Nefedova, 2007). The large-scale enterprises temporarily used the barter changes of their products for machinery and other agricultural inputs.

The basic idea of the reformers was right: it was necessary to put an end to the state command in agriculture. The contract teams were the first step on the path to the revival of peasant consciousness. The agricultural producers - either fermers promoted in the early 19gos or large-scale enterprises - became the "masters" of all production decisions at their own risk. Not this conception but the wrong assessment of the situation at the Russian food market was the reason of the decade-long agricultural decline in the 1990s. Only in the 2000s, the new structure of agriculture developed fully to ensure in the next decade the growth of the agricultural productivity (plant and livestock production yields) higher than the Soviet level. This result was also achieved by the new state approach to agriculture in 2000, which was based on the state support and food security policy. Thus, after nearly a century, Russia finally returned to grain exports at the world market (Wegren, Nikulin, Trotsuk, 2018; Merl, 2019).

Under the general food crisis, it was reasonable to allow to use land primarily for one's food supplies. Besides few household producers who wanted to develop their farming, the majority became temporary agrarian producers of food for consumption and local markets, although their labor productivity and yields were much below the average (Pallot, Nefedova, 2007) for there were many elderly people in the remote rural areas with low pensions. However, on the 19gos, the production share of these households (except for grain and industrial crops) was significant: in 2000 , they produced $5^{8}$ percent of the cattle and poultry, $5^{1}$ percent of milk, 81 percent of potatoes and 71 percent of vegetables (Rossissky..., 2017: 363). After 2005, their share began to decrease especially in meat production, but in 2016 , with 44 percent of milk production, 78 percent of potatoes and 67 percent of vegetables they still contributed significantly to the people's food supply (Rossissky..., 2017; Wegren, Nikulin, Trotsuk, 2018). Their share of production increasingly declined in the following years, and in about two or three decades they would have looked like German allotment gardens (Schrebergärten) that played an important role under the food crises after the World War II. Today they mostly serve for leisure, growing flowers and some fruits and vegetables for the mar-
79

S. Merl

Agricultural

reforms in Russia

from 1856 to the

present: Successes

and failures in

the international

comparative

perspective 
80 ket prices for food are reasonable. Such a development is very likely for Russia, when new generations will no longer enjoy hard work at the household plots.

Putin's stabilization is based on the revival of the domestic demand. In the 2000s, urban incomes increased significantly and, thus, the demand for food, while the share of imports decreased (Wegren, Nikulin, Trotsuk, 2018). The new state subsidies played an important role by making agriculture attractive for capital investors even not from the agricultural sector.

Today's success is based on the fundamental reorganization of agriculture by privatization in the early 1990s - enterprises and farms decide on inputs on their own and use the internationally available highly productive inputs (machinery and cattle breeds, fertilizers and pesticides) (Merl, 2019). This led to the remarkable increase in yields surpassing any numbers of the Soviet command agriculture and finally catching up in productivity with the leading western countries. The share of agriculture and forest industry in the Russian employment decreased from 13.9 percent in 2000 to 7.5 percent in 2016 (Rossiisky..., 2017: 114). However, this share is four times larger than in Germany. The growth of yields is typical for agroholdings - successfully reorganized state and collective farms - and for some family farms - the result of the fermer movement. The average yields shown in the statistical data often do not present the real increase for they show only for total production including the household sector. Only the data on milk per cow for corporate enterprises is available: in 2016 , they produced $5370 \mathrm{~kg}$ of milk per cow (in $1985-2334 \mathrm{~kg}$, in $1990-2731 \mathrm{~kg}$ ), while the average yield for all producers in 2016 was only $4218 \mathrm{~kg}$ per cow. As the agroholdings provide about 50 percent of production, the other 50 percent is provided mainly by the household sector with about $3000 \mathrm{~kg}$ per cow (slightly above the Soviet level) (Merl, 2019: 52).

However, large-scale enterprises and households providing each a half of the milk production is a somewhat misguiding picture. Market production comes primarily from corporate enterprises and family farms with more than 100 hectares of land. Today only these producers modernize their production, which extremely increases their yields. The rest of the producers - households, small family farms and some of the still existing state and collective farms - hardly take part in the market production, although they benefitted from using better seeds, leasing machinery, etc. Thus, today the agricultural sector is divided: some producers modernize their production and some do not; only the former will stay crucial for the future.

Since the early 2000 s, there is a new trend: many large enterprises that emerged from the collective and state farms went bankrupt and/or were bought up by investors to create vertical holdings (Leonard 2011: 111-112). While most of the registered corporate enterprises in 2000 were still the remains of former collective and state farms, 
in 2010, holdings got the largest share of land: for instance, in the south some of them reached hundreds of thousands of hectares. The whole-sale and retail food networks looking for large quantities of production of the standard high quality decided to create their own agricultural holdings. The former collective and state farm survived mainly on the less fertile soils in remote areas. Corporate enterprises still keep or increase their share in meat production (cattle and poultry, from 40 to 76 percent from 2000 to 2016) and milk production (from 45 to 49 percent). In grain and industrial crops production, their share is very high (though they slightly lose to private farms), but they produce only 14 percent of potatoes and 18 percent of vegetables (Rossiisky..., 2017: 363 ).

More than 250,000 families joined the fermer movement from 1992 to 1995 , and quite many did it voluntarily. Only a small group of workers was very dissatisfied with the production processes under the state command and was ready to take the risk of becoming the new masters of the agricultural production. Many fermers were representatives of the former management of the agricultural farms or left the industry to enjoy the new freedom without the state command. In general, the situation was similar to the former GDR (Merl, 2017c). According to Pallot and Nefedova (2006), some fermers came from the former contract teams and brigades, some were forced to become fermers after their agricultural enterprises fell apart and stopped production. Many fermers in the early 1990s used their networks successfully to organize tractor and farm implements supplies. However, many failed in the end primarily due to the crisis of the 199os.

It is still difficult to assess successes and failures of private farming on the basis of the statistical data for it includes many "dead souls". The Russian peasant association ACCOR tries to prove the importance of private farms by inflating the numbers, but does not present the most important figures such as the average plant and livestock production yields at peasant farms. While in 1995 279,200 peasant farms were registered, their number felt only to 257.400 in 2006 and to 174,800 on July 1, 2016. Only a part of the registered fermers is engaged in production, some (20 percent in 2016) do not even have arable land. According to the official data, their average size in hectares was 43 in 1995, 75- in 2006, and 248 - in 2016 (Rossiisky..., 2001: $404 ; 2006: 444 ; 2017: 378,380)$. It is likely that more than a half of the official figure (especially farms with less than 20 hectares) produce only to satisfy their own needs.

To assess the prospects of peasant farms, it is necessary to consider their investments in the modernization of their economy and if the number of such farms grows. After 2000, peasant farms with 200 and more hectares had about $2 / 3$ of the peasant-farm sector land. There were 13,000 farms in this group at the end of $2000,18,100$ - at the end of 2005 , and 35,600 - in July 2016. Thus, an increasing part of the registered peasant farms develop successfully. To identify the real

\section{S. Merl}

Agricultural reforms in Russia from 1856 to the present: Successes and failures in the international comparative perspective 
number of the modernizing peasant farms we have to consider also those with 20 to 200 hectares - from 50,000 to 100,000 farms. There

история is also regional differentiation: the largest peasant farms can be found in the Volga Region and West Siberia (already in 2004 the average size was 130 to 160 hectares), the smallest farms are more common on the more fertile soils of the Northern Caucasus (in 2004 - about 30 hectares) (Pallot, Nefedova, 2007: 170-174).

The share of private farmers is still insignificant in meat production (it increased from 2 to 3 percent from 2000 to 2016). This sector became the most important in grain production and increased its share from 8 to 28 percent, while in milk production - from 2 to 7 percent, in the industrial crops production - from 29 to 31 in sun flower seeds, from 10 to 12 - in sugar beets, in vegetables - from 10 to nearly 15 percent, in potatoes - from 5.8 to 8.5 (Rossiisky..., 2017: 363 ).

To what extent did the fermers share the typical "peasant values" of giving up quick profits to ensure sustainable agricultural production, soil and environment protection? The available data does not provide answers to this question, but it is likely that private farms are more "peasant" in this sense than the majority of agroholdings. I doubt that agroholdings really care about sustainable agriculture; many capital owners are interested in agriculture just to make money. Agroholdings focus on that part of the production, in which mechanization and demand promise the biggest effect (and profits), and rarely think about sustainability. Therefore, it will be a priority for the future Russian agricultural sector not to allow agroholdings but to help peasant (family) farms to replace the household sector, which will also reduce the risks of the mono-(large-scale) structure of agriculture. To help the family farms to develop and strengthen, the state support (like from 1906 to 1928) is desirable. It is also necessary to support large farms that need well trained personnel and consulting agencies for marketing and investment. State investments in the local infrastructure (roads, services and living conditions) will play a decisive role. Taking into account the need in viable farms using the new agricultural technologies, the number of peasant farm for replacing the household sector can be quite small (Merl, 2017c).

\section{Conclusion}

The reform period after the emancipation successfully started to overcome both main obstacles on the way to the agricultural modernization to catch up with the developed countries: underemployment of the rural workforce and lack of demand for the high-value agricultural production. As both depended on the external impulses, industrialization and state support were indispensible. The expert assessments and proposals for the final version of the first five-year plan 
were convinced of the viability of the peasant agriculture in the 1930s. However, the forced collectivization put an end to reforms by destroying the agricultural productive forces and, thus, aggravating the persistent rural underemployment. Under the state command, the socialist agriculture did not allow the heads of the large-scale agricultural enterprises (unlike the directors of industrial enterprises) to master their production, and, thus, failed to keep up with the western agriculture. After Stalin's death, the plan to increase efficiency (yields and agricultural labor productivity) by the complex mechanization failed. Until the very end of the Soviet period, the majority of agricultural workers used manual labor. Several popular myths about the Soviet agriculture can be debunk: that there was no chance to develop family farms in the late 1920s; that mechanization in the 1930 s was necessary or contributed to modernization of agriculture; and that the "socialist industrial" agriculture managed the complex mechanization.

Starting from the reform of 1987 , an important part of the Russian agriculture is still under modernization and increases yields to finally catch up with the western agriculture. The new approach partly followed the successful development of peasant farms until 1928. The end of the state command was the only way for the successful reform in 1987. The agricultural depression of the 199os was the legacy of collectivization and the state command system, which hindered modernization of agriculture: machinery industry, transport, processing, storage and trading - all were in very poor condition. Under the general economic stabilization and the effective market-oriented state support for agriculture, the reform showed positive results such as increasing efficiency and changing agricultural structure. Thus, the household sector increasingly loses positions in production; with a half share of the agricultural production the corporate/holding sector works increasingly effectively. However, the further growth of the latter is risky for a part of its capital is invested with speculative purposes, and huge enterprises of hundreds of thousands of hectares bear the high risk of bankruptcy and idle arable land.

\section{References}

Barsov A.A. (1969) Balans stoimostnykh obmenov mezdu gorodom i derevnej [Balance of Value Exchanges Between City and Village]. Moscow.

Beyrau D. (1981) Reformen und soziale Beharrung im ländlichen Russland. G. Schramm (Ed.). Handbuch der Geschichte Russlands: Von den autokratischen Reformen zum Sowjetstaat (1856-1945)., Stuttgart: Hiersemann, pp. 14-68.

Bruisch K. (2014) Als das Dorf noch Zukunft war. Agrarismus und Expertise zwischen Zarenreich und Sowjetunion. Köln: Böhlau Verlag.

Davies B., Wheatcroft S.G. (2004) The Years of Hunger. Soviet Agriculture, 1931-1933 (Industrialisation of Soviet Russia 5). Basingstoke: Palgrave Macmillian.

GAYO (Gosudarstvenny Arkhiv Yaroslavlskoi Oblasti) [State Archive of the Yaroslavl Region], Filial CDNI, Fond 272.
83

S. Merl

Agricultural

reforms in Russia

from 1856 to the

present: Successes

and failures in

the international

comparative

perspective 
Gorshkov B.B. (2018) Peasants in Russia from Serfdom to Stalin. Accommodation, Survival, Resistance. London: Bloomsbury Academic.

Gregory P.R. (1982) Russian National Income, 1885-1913. Cambridge: Cambridge University Press.

Herzberg J. (2013) Gegenarchive. Bäuerliche Autobiographik zwischen Zarenreich und Sowjetunion. Bielefeld: Transkript.

Hildermeier M. (2013) Geschichte Russlands. Vom Mittelalter bis zur Oktoberrevolution. München: Beck.

Hoch S.L. (1994) On good numbers and bad population trends and peasant standard of living in late imperial Russia. Slavic Review, vol. 53, pp. 41-75.

Hoch S.L. (2004) Did Russia's emancipated serfs really pay too much for too little land? Statistical anomalies and long-tailed distributions. Slavic Review, vol. 63, pp. 247274.

Hunter H., Szyrmer J.M. (1992) Faulty Foundations. Soviet Economic Policy 1928-1940. Princeton: Princeton University Press.

Jaehne G. (1976) Landwirtschaft und Gesamtwirtschaft. Sowjet-Landwirtschaft heute. Berlin: Duncker \& Humblot, pp. 19-66.

Jaehne G. (Ed.) (1981). Sowjet-Landwirtschaft 1981. Berlin: Duncker \& Humblot.

Krebs Chr. (1983) Die weltanschaulichen und wirtschaftstheoretischen Grundlagen der Agrartheorie im Marxismus-Leninismus. Berlin: Duncker \& Humblot.

Leonard C.S. (2011) Agrarian Reform in Russia. The Road from Serfdom. Cambridge: Cambridge University Press.

Lincoln W.B. (1992) The genesis of an "enlightened" bureaucracy in Russia, 1825-1856. Jahrbücher für Geschichte Osteuropas, vol. 20, pp. 321-330.

Medvedev Z.A. (1987) Soviet Agriculture. New York: Norton \& Company.

Merl S. (1981) Der Agrarmarkt und die Neue Ökonomische Politik. Die Anfänge staatlicher Lenkung der Landwirtschaft in der Sowjetunion 1925-1928. München, Wien: Oldenbourg.

Merl S. (1985b) Die Anfänge der Kollektivierung in der Sowjetunion. Der Übergang zur Staatlichen Reglementierung der Produktions-und Marktbeziehungen im sowjetischen Dorf (1928-1930). Wiesbaden: Otto Harrassowitz.

Merl S. (1985a) Handlungsspielräume und Sachzwänge in der sowjetischen Wirtschafts-und Sozialpolitik der Zwischenkriegszeit. W. Fischer (Ed.). Sachzwänge und Handlungsspielräume in der Wirtschafts - und Sozialpolitik der Zwischenkriegszeit. St. Katharinen: Scripta Mercaturae, pp. 175-229.

Merl S. (1990a) Bauern unter Stalin. Die Formierung des sowjetischen Kolchossystems, 19301941. Berlin: Duncker \& Humblot.

Merl S. (199ob) Sozialer Aufstieg im sowjetischen Kolchossystem der 3oer Jahre? Über das Schicksal der bäuerlichen Parteimitglieder, Dorfsowjetvorsitzenden, Posteninhaber in Kolchosen, Mechanisatoren und Stachanowleute. Berlin: Duncker \& Humblot.

Merl S. (1991) Kollektivierung und Bauernvernichtung. D. Geyer (Ed.). Die Umwertung der sowjetischen Geschichte. Göttingen, pp. 103-132.

Merl S. (Ed.) (1993) Sowjetmacht und Bauern. Dokumente zur Agrarpolitik und zur Entwicklung der Landwirtschaft während des "Kriegskommunismus" und der Neuen Ökonomischen Politik. Berlin: Duncker \& Humblot.

Merl S. (1995) Golod 1932-1933 godov — genotside Ukraintsev dlja osushchestvleniya politiki rusifikatsii? [Famine of 1932-1933 - genocide of the Ukrainians as a part of the russification policy?]. Otechestvennaya istoriya, no 1, pp. 49-61.

Merl S. (1999) Einstellungen zum Privateigentum in Russland und in der Sowjetunion (19.-20. Jahrhundert). D. Sugarman, H. Siegrist (Eds.). Eigentum im internationalen Vergleich: 18-20 Jahrhundert, Göttingen, pp. 135-160.

Merl S. (2002a) Entstalinisierung, Reformen und Wettlauf der Systeme 1953-1964. S. Plaggenborg et. al (Eds.). 1945-1991. Vom Ende des Zweiten Weltkriegs bis zum Zusammenbruch der Sowjetunion. Anton Hiersemann, pp. 175-318. 
Merl S. (2002b) Itogi podchineniya - socialnaya i ekonomicheskaya reorganizatsiya derevni [Results of the submission - social and economic reorganization of the village]. Yaroslavsky pedagogichesky vestnik, no 3, pp. 19-35.

Merl S, (2008) Bauern in Kreditgenossenschaften: "Träume" und “Albträume" der Staatsbank-Inspektoren, 1905-1917. W. Sperling (Ed.). Jenseits der Zarenmacht. Dimensionen des Politischen im Russischen Reich, 1800-1917. Frankfurt/M-New York: Campus, pp. 279-311.

Merl S. (2011) Sowjetisierung in Wirtschaft und Landwirtschaft. Europäische Geschichte Online (EGO). Mainz: IEG.

Merl S. (2013) Kooperativnoe dvizhenie v tsarskoj Rossii i pervye gody sovetskoj vlasti: rol v natsionalno-gosudarstvennom stroitelstve [Cooperative movement in imperial Russia and in the first years of the Soviet power: Its role in the national-state building]: Krestyanovedenie. Teoriya, Istoriya, Sovremennost. Uchenye Zapiski, no 8, pp. 51-101.

Merl S. (2016) Why did the attempt under Stalin to increase agricultural productivity prove to be such a fundamental failure? On blocking the implementation of progress in agrarian technology (1929-1941). Cahier du Monde Russe: Terres, sols et peuples: Expertise agricole et pouvoir (XIX-XX siècles), vol. 57, no 1, pp. 191-220.

Merl S. (2017a) Sovetskaya ekonomika; sovremennye ochenki [Soviet economy: Contemporary essays]. Ekonomicheskaya istoriya. Moscow, pp. 303-349.

Merl S. (2017b) The peasants and the October Revolution. Velikaya rossiiskaya revoljutsiya 1917: 100 let izucheniya. Moscow, pp. 453-46o.

Merl S. (2017C) Agrarian transformation in the former GDR in 1989-2017: A success story? Russian Peasant Studies, vol. 2, no 4, pp. 130-147.

Merl S. (2018) Slavery in North America and serfdom in Russia in comparison: The role of civil society in its abolishment. Britaniya: Istoriya, kultura, obrazovanie. Yaroslavl, issue 4, pp. 416-424.

Merl S. (2019) Reassessment of the Soviet agrarian policy in the light of today's achievements. Russian Peasant Studies, vol. 4, no 1, pp. 45-69.

Miller R.F. (1970) One Hundred Thousand Tractors. Cambridge: Cambridge University Press.

Moon D. (1999) The Russian Peasantry 1600-1930. The World the Peasants Made. LondonNew York: Longman.

Moon D. (2001) The Abolition of Serfdom in Russia, 1762-1907. Harlow.

Narodnoe khoziaistvo SSSR za 70 let (1987) [Soviet National Economy for 70 Years]. Jubileiny statistichesky ezhegodnik. M: Finansy i statistika.

Pallot J., Nefedova T. (2007) Russia's Unknown Agriculture. Household Production in Post-Communist Russia. Oxford: Oxford University Press.

Popov G. (1989) Dva tsveta vremeni ili uroki Chrushcheva [Two colors of the time, or Khrushchev's lessons]. Ogonek, no 42, pp. 14-17.

RGAE (Rossiisky Gosudarstvenny Archiv Ekonomiki) [Russian State Economic Archive], Fond 7486 (Narodny kommissariat zemledeliya SSSR), Opis 1.

RGANI (Rossiisky Gosudarstvenny Archiv Noveishei Istorii) [Russian State Archive of Contemporary History], Fond 5 .

Rossiisky statistichesky ezhegodnik (2001, 2006, 2017) [Russian Statistical Yearbook]. Moscow.

Schedewie F. (2006) Sozialer Protest und Revolution im Landwirtschaftlichen Zentrum Rußlands: Die Bauernaufstände im Kreis Ostrogozsk, 1905-1907. H.D. Löwe (Ed.). Volksaufstände in Rußland. Von der Zeit der Wirren bis zur "Grünen Revolution" gegen die Sowjetherrschaft. Wiesbaden: Harrasowitz, pp. 453-496.

Scheibert P. (1973) Die russische Agrarreform von 1861. Ihre Probleme und der Stand ihrer Erforschung. Köln-Wien: Böhlau.

Schinke E. (1967) Die Mechanisierung landwirtschaftlicher Arbeiten in der Sowjetunion. Wiesbaden: Harrassowitz.

Schmieder M. (2017) "Fremdkörper im Sowjet-Organismus". Deutsche Agrarkonzessionen in der Sowjetunion 1922-1934. Stuttgart: Franz Steiner Verlag.

Selkoe khozyaistvo (1988) [Agriculture]. Statistichesky sbornik.

RUSSIAN PEASANT STUDIES $2020 \cdot$ VOLUME $5 \cdot$ No 2 
Selkoe khozyaistvo Rossii (1995) [Agriculture]. Statistichesky sbornik.

Shanin T. (1972), The Awkward Class. Political Sociology of Peasantry in a Developing Society. Russia 1910-1925. Oxford: Oxford University Press.

Sikor T., Dorondel S., Stahl J., Xuan To P. (2017) When Things Become Property. Land Reform, Authority, and Value in Post-Socialist Europe and Asia (Max Planck Studies in Anthropology and Economy, no 3). New York-Oxford: Berghahn.

Transcript (1998) of the conversations between the Soviet leadership and a Hungarian United Worker" delegation in Moscow on June 13, 1953. Cold War International History Project. Bulletin 10, pp. 82-86.

Wolf M. (1928) O krestjanskom sovkhoze [On the peasant state farm]. Pravda. 6.6-11.7.1928.

Wädekin K.-E. (1969) Die sowjetischen Staatsgüter. Expansion und Wandlungen des Sovchozsektors im Verhältnis zum Kolchozsektor von Stalins Tod bis heute. Wiesbaden.

Wädekin K.-E. (1976) Arbeitskräfte - Mangel und Überschuss. Sowjet-Landwirtschaft heute. Berlin: Duncker \& Humblot, pp. 197-212.

Wegren S.K., Nikulin A., Trotsuk I. (2018) Food Policy and Food Security. Putting Food on the Russian Table. Lexington: Lanham.

\section{Российские аграрные реформы с 1856 года по настоящее время: успехи и провалы в международном сопоставительном контексте}

Штефан Мерль, доктор исторических наук, профессор Билефельдского университета; Университетштрасе, 25, 33615, Билефельд, Германия.

E-mail: smerl@uni-bielefeld.de

Несмотря на свою изначальную отсталость, аграрный сектор играл решающую роль в российской/советской истории. До 1950-х годов он был основным сектором занятости и вносил огромный вклад в валовый внутренний продукт и валовую стоимость, пока принудительная коллективизация не уничтожила значительную часть сельскохозяйственных ресурсов. Автор утверждает, что освобождение крестьянства проложило путь для аграрной модернизации страны, формируя новую сельскохозяйственную структуру, основанную на рынке и экономических навыках глав крупных и семейных хозяйств. В статье обозначено три российских/советских подхода к аграрному реформированию (1856-1928, 1929-1987, с 1987 года) с точки зрения вклада в модернизацию сельского хозяйства и догоняющую стратегию по отношению к развитым странам. Автор полагает, что до 1928 года и (после аграрного спада 1990-х годов) с 2000 года Россия была успешна как в модернизации, так и в догоняющем развитии, хотя сталинская принудительная коллективизация сначала и породила застой. После Второй мировой войны коллективизация стала препятствием для какой бы то ни было версии “зеленой революции" (т. е. применения аграрных научноисследовательских достижений). В условиях административно-командной системы слабая механизация не позволила увеличить производительность труда в сельском хозяйстве. Хотя Россия была известна сельскохозяйственными излишками еще до коллективизации, в последние годы своего существования Советский Союз был главным мировым импортером зерна. Только реформирование, начатое в 1987 году, устранило государственный административно-командный подход из сельского хозяйства, чтобы сделать сельскохозяйственных производителей вновь хозяевами собственных полей, что обусловило значительный рост производительности с 2005 года. Опираясь в переоценке аграрных реформ прошлого на недавние успехи, статья формулирует вопросы для дальнейших научных дискуссий. В частности, автор предлагает рассмотреть использование имеющейся сельской рабочей силы, 
качество индустриальных ресурсов в сельском хозяйстве и степень, в которой сельскохозяйственные производители могли выступать полноправными хозяевами своего производства, - как наиболее адекватные критерии для оценки результатов аграрных реформ.

Ключевые слова: аграрная реформа, эффективность аграрного производства, освобождение, принудительная коллективизация, зеленая революция, механизация сельского хозяйства, модернизация, крестьянские хозяйства, сельская неполная занятость, социалистическое индустриальное сельское хозяйство, Александр II, Сталин, Брежнев, Хрущев, Горбачев, Путин
87

S. Merl

Agricultural

reforms in Russia from 1856 to the present: Successes and failures in the international comparative perspective 